\title{
Expressing Distance in the Baltic Languages: Remarks on the Use of an Extended RCC
}

\author{
Eglè ŽILINSKAITE்-ŠINKŪNIENE ${ }^{1}$, Jurgis ŠĶILTERS ${ }^{2,1}$, \\ Līga ZARIN,A ${ }^{2}$ \\ ${ }^{1}$ Vilnius University, Institute for the Languages and Cultures of the Baltic, Faculty of Philology, \\ Universiteto st. 5, Vilnius, Lithuania \\ ${ }^{2}$ University of Latvia, Laboratory for Perceptual and Cognitive Systems at the Faculty of \\ Computing, Faculty of Computing, Raina blvd. 19, Rīga, Latvia \\ egle.zilinskaitedflf.vu.lt, jurgis.skilterselu.lv, \\ liga.zarina@lu. lv
}

\begin{abstract}
The aim of this paper is to demonstrate how the distance between two objects is expressed in the Baltic languages in a geometric framework. The geometric framework in this research is based on Region Connection Calculus (Randell et al., 1992), representing different spatial relations between two circles depending on the primitive topological relation of connectedness and extended with the operators of distance (near / far) and orientation (left / right, above / below, oblique). The paper summarizes the results of two experiments conducted with 106 Lithuanian and 105 Latvian participants, and provides an interpretation of 15 stimuli with the emphasis on the usage of the terms that express proximity, remoteness and which specify distance. Our results indicate different determining factors for the use of these three groups of terms. Proximity terms clearly depend on the change in distance: as the distance between the circles decreases, the number of proximity terms increases, but the largest number of them is generated for externally connected circles. In addition, the largest number and variety of proximity terms are produced for the horizontal axis, less - for the oblique, and least - for the vertical. The terms indicating remoteness are most compatible with the greatest distance between the circles and with horizontal axes as well. The usage of the distance-specifying phrases, in contrast, does not depend on axis and increase or decrease in distance. The presence of any distance seems to be a determining factor for attempting to express it in certain measurements.
\end{abstract}

Keywords: distance, near, far, RCC, geometry, the Baltic languages.

\section{Introduction}

Within static non-angular spatial relations, containment and support have received most attention in linguistic and psycholinguistic research due to several reasons. There has been ample evidence on the polysemy of the terms expressing containment and support attempting to define the determining principles for the usage of these terms in spatial domains, and to explain the meaning extensions into abstract domains (Herskovits, 1986; Navarro, 1998; Feist, 2000, Jamrozik and Gentner, 2011 among others). Another 
important question was raised about the importance of geometry vs. function or forcedynamic factors and their impact for the use of containment and support terms. Earlier geometric approaches (e.g., Cooper, 1968; Bennett, 1975) were considered insufficient for explaining all the use-types of prepositions positing a functional approach as more plausible (Vandeloise, 1991, 1994; Coventry et al., 1994; Coventry and Garrod, 2004; cf. Landau, 2017). In addition, containment and support relations have attracted much attention because of the cross-linguistic similarities and variation, which provides evidence that languages may structure spatial domain extremely differently (Bowerman and Pedersen, 1992; Bowerman and Choi, 2003; Levinson and Wilkins, 2006; Gentner and Bowerman, 2009; Landau et al., 2017; Feist and Zhang, 2019).

In comparison to containment and support, proximity has been rather underexamined. Studies in linguistic semantics largely deal with polysemy of proximity adpositions, and the explanatory procedures behind it (e.g., Herskovits, 1986; Vandeloise, 1991; Navarro, 1998, see also Cienki, 1989, Šarić, 2006 for Slavonic languages). Functional geometric framework sees proximity depending on the distance between the objects involved, their size, mobility and environment (small- vs. largescale) (Coventry and Garrod, 2004), as well as the speed of the speaker and addressee (Vandeloise, 2017). Vandeloise (idem) proposes the notion of accessibility as determining NEAR/FAR prepositions: near is used when the Figure is easily accessible to the Ground, but far from - vice versa. However, it seems that angular proximity and the choice of certain frames of reference have received more attention (Levinson, 2003; Majid et al., 2004; Levinson and Wilkins, 2006, among others), not to mention demonstratives and proximal-distal distinction, which is under thorough cross-linguistic exploration (Coventry et al., 2008; project of Deictic Communication ${ }^{1}$ ).

Intuitively used relational spatial language has been made more precise in Qualitative Spatial Reasoning formalisms (for an overview cf. Forbus, 2018). These formalisms are usually equipped with a first order language expressing relationships between spatial objects without numerical and measurement-sensitive components.

Region connection calculus (RCC; Randell et al., 1992; Cohn et al., 1997) is one of the most prominent frameworks of qualitative spatial reasoning, assuming a set of core topological relations that can be used for expressing a variety of relational spatial information. There are several advantages of the RCC if compared to other spatial formalisms (for an overview regarding qualitative spatial reasoning and the languages of qualitative formal representation cf. Forbus, 2018): (1) RCC assumes region as the main spatial primitive (instead of a point or point-sets); this enables a cognitively adequate way of expressing space, because in everyday situations, we are confronted with spatially extended objects or regions instead of points that are mathematical abstractions and cannot be found in the physical world; (2) RCC contains all necessary relations for representing topological variations in the physical world of human interactions. However, two objections are worth keeping in mind: (3.1) although RCC relations are necessary for representing space, they are not sufficient as some crucial and frequently used spatial (e.g., geometric) relations are still lacking in the set of classical RCC (e.g., distance, orientation, and convexity operators are unavoidable in most relational reasoning situations); (3.2) the RCC cannot explain the functional dependencies between everyday objects (e.g., relations of support and containment cannot be straightforwardly

\footnotetext{
${ }^{1}$ http://www.dcomm.eu.
} 
represented in the RCC). Taking into account objections 3.1 and 3.2, RCC should be enriched both geometrically and functionally.

There have been several attempts to apply extended and modified versions of RCC to natural language analysis (e.g., Mani and Pustejovsky, 2012; Rodrigues et al., 2017; Vasardani et al., 2017). Although there is work on the subject in English, the Baltic languages have received only some attention in this respect (Žilinskaitè-Šinkūnienè et al., 2019a, Šķilters et al., submitted, Škilters et al., MS.). Having extended RCC framework with the primitives of distance, size, orientation and partial occlusion, we have analyzed the expressions of the relations of containment and support as well as the determining factors underlying these expressions (Žilinskaitè-Šinkūnienè et al., 2019a). We have found that axial information and external connectedness are the most prominent factors which are interpreted rather similarly in both Lithuanian and Latvian. In addition, we have also examined how containment and support are expressed in typical spatial routines, using the set of stimuli with everyday objects. The results of the latter research show a large intra-linguistic and cross-linguistic variation (Žilinskaitè-Šinkūnienè et al., 2019b, cf. Bowerman and Pedersen, 1992; Bowerman and Choi, 2003; Levinson and Wilkins, 2006; Gentner and Bowerman, 2009; Landau et al., 2017). If the results of our two studies are compared, we observe that in the RCC+F framework participants concentrate more on orientational or positional properties of the spatial relation, whereas the same spatial relation between everyday objects is expressed by the means presupposing their functional interaction (e.g., support prepositions) or avoiding terms that geometrically refer to the inner region (such as inside, middle, center for containment).

In our current study, we are focusing on the distance operator (expressed in primitives FAR and NEAR); we aim to clarify the usage of proximity terms in the Baltic languages within an extended RCC framework $(\mathrm{RCC}+\mathrm{F})$. It mainly focuses on the following questions: (a) which proximity terms are employed; (b) is there a difference between the use of these terms and what properties sanction and constrain the occurrence of them.

\section{The experiment}

\subsection{Stimuli}

In order to test the usage of the proximity relations and proximity terms in RCC framework, we used an extended version of the RCC, namely, RCC+F (Škilters et al., MS). RCC deals with basic topological relations between two regions and is based on a primitive topological relation of connectedness $(C)$. From this relation, the rest of classical RCC relations are derived: disconnectedness $(D C)$, external connectedness $(E C)$, partial overlap $(P O)$, tangential proper-part $(T P P)$ and inverse relation of tangential proper-part (TPPi), non-tangential proper-part $(N T P P)$ and inverse relation of non-tangential proper-part (NTPPi). In our approach (which is a part of RCC+F), RCC was extended with orientational, distance, and size primitives, such as partial occlusion, orientation (left, right, above, below, oblique), and distance (near / far), and size (small / large). The stimuli used in this paper are summarized in Table 1. 
Table 1. Stimuli labels and variables analyzed in this paper

\begin{tabular}{|c|c|c|c|c|c|c|c|c|}
\hline & \multicolumn{9}{|c|}{ ORIENTATION } & \\
\hline RCC & left & right & above & below & $\begin{array}{c}45^{\circ} \text { right } \\
\text { above }\end{array}$ & $\begin{array}{c}45^{\circ} \text { left } \\
\text { below }\end{array}$ & $\begin{array}{c}45^{\circ} \text { right } \\
\text { below }\end{array}$ & $\begin{array}{c}\text { DIS- } \\
\text { TANCE }\end{array}$ \\
\hline DC & 7 & 5 & 6 & 8 & & & 18 & Close \\
\hline DC & 3 & 1 & 2 & 4 & 17 & & & Far \\
\hline EC & 11 & 9 & 10 & 12 & & 19 & & - \\
\hline
\end{tabular}

Each stimulus is characterized by an RCC relation ( $D C$ or $E C$ ), orientation (horizontal, vertical, or oblique axial alignment) and distance (near and far in the cases when the circles are disconnected). The numbers in the Table 1 reflect the original numeration of the stimuli as it was during the experiment. The actual stimuli are given in Table 2. Each stimulus depicts a spatial scene which consists of two circles: the dark one (the Figure) and the light one (the Ground). The terms are used as in (Talmy, 2000): the Figure is the central element that has to be located, whereas the Ground is the reference object enabling to locate the Figure.

Table 2. Stimuli for analysis

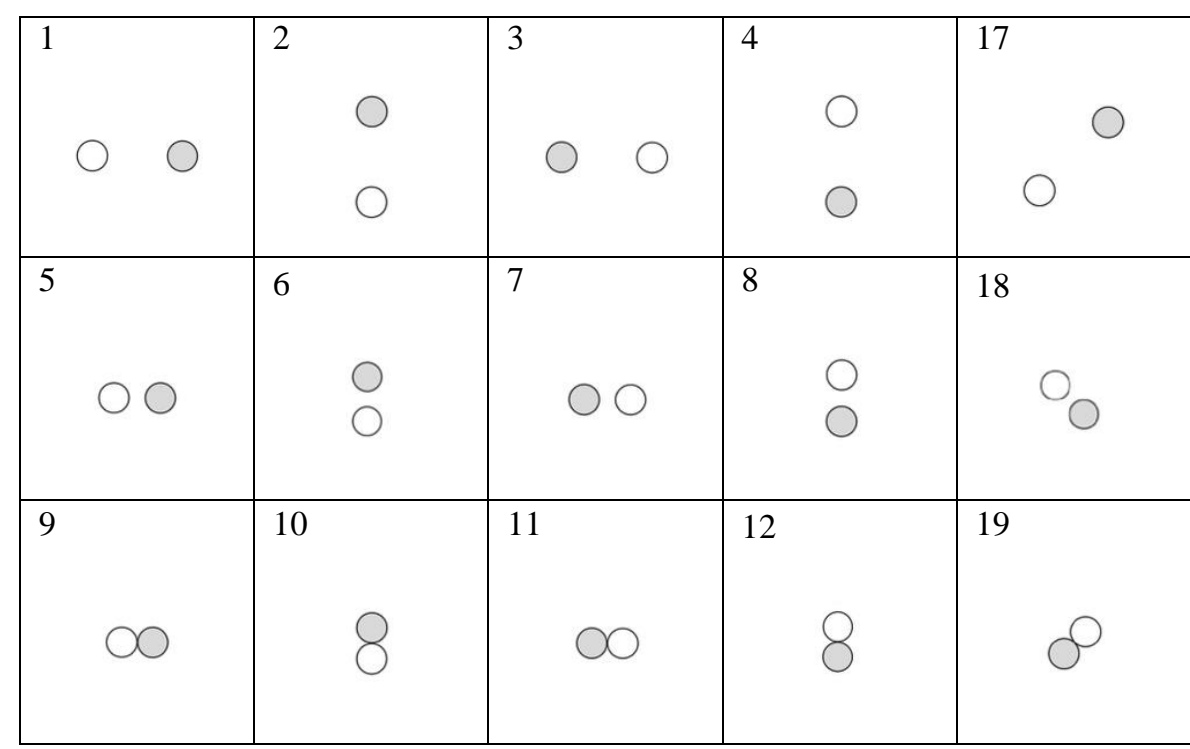

\subsection{Task design and procedure}

An in-group (repeated measures) experiment was conducted in two formats: a paperand-pencil task (henceforth - p-task) and an electronic task created with QuestionPro ${ }^{\mathrm{TM}}$ tool (henceforth - e-task). Both tasks consisted of the same stimuli set containing 31 stimuli. Each stimulus represented two circles: the light and the dark one, provided in a randomized order to each participant. Each stimuli set was preceded by a short 
instruction introducing the task and was followed by a demographic questionnaire containing questions about gender, age, nationality, native tongue, foreign language skills, level and field of education, occupation, place where a participant has spent most of her/his life, hobbies and handedness. Under each stimulus was the question "Where is the dark circle?", and the participants were tasked with describing the location of the dark circle in relation to the light one. We chose a partially open-ended production task (Carlson and Hill, 2003), where the beginning of the response was already given (The dark circle...). The average time to complete the electronic task was approximately 14 minutes for both Lithuanian and Latvian participants. All the results were manually coded in Excel and analyzed using descriptive statistics tools. Statistical t-test was conducted by software SPSS Statistics 22.

\subsection{The participants}

The p-task was carried out by 45 Lithuanian and 45 Latvian native speakers and the etask - by 61 Lithuanian and 60 Latvian participants. Male / female distribution was almost equally balanced for the e-task (51\% women and $49 \%$ men for LT and 52\% women and $48 \%$ men for LV) but there were more male participants for the p-task ( $44 \%$ women and $56 \%$ men for LT and 30\% women and $70 \%$ men for LV).

The age distribution of the participants is given in Figure 1. The age distribution of Latvians was similar in both tasks (p-task/e-task) - younger than 25 : 41\%/30\%; 25-34: 23\%/27\%; 35-44: $16 \% / 23 \%$; 45-54: 9\%/8\% and older than 55: 11\%/12\%). The sample of Lithuanian participants has a different age-distribution: the p-task was filled by $73 \%$ participants under age of $25,7 \%$ participants were in the age group $25-34 ; 11 \%$ and $9 \%$ were in the age groups $35-44$ and over 55 . The e-task was filled by $15 \%$ of participants younger than 25, while most participants were in the age groups 25-34 (44\%) and 35-44 (31\%), while $10 \%$ were older than 55 .

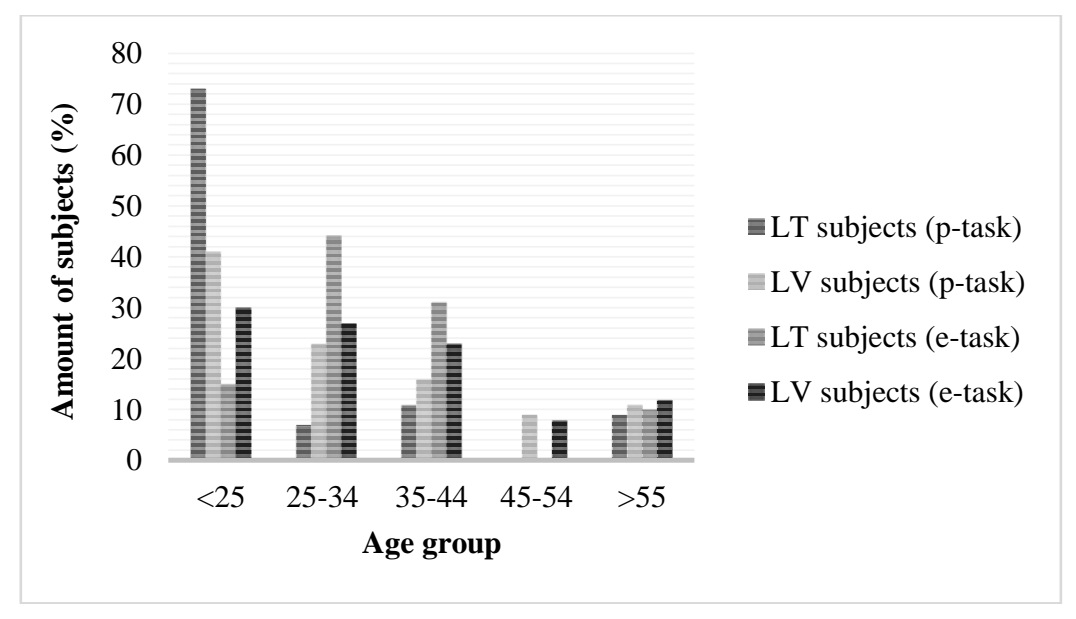

Figure 1. The age distribution (\%) of LT and LV participants for both tasks

Almost all of the participants were native speakers of the language in which they filled in the questionnaire. In both tasks, 2 Lithuanian and 3 Latvian participants 
indicated Russian as their mother tongue. $1 \mathrm{LV}$ participant noted Yiddish as their mother tongue in the p-task, but in the e-task, other languages as native were indicated by 1 Lithuanian and 2 Latvian participants. $91 \%$ of both Lithuanians and Latvians reported English as the first most well-spoken foreign language and 56\% Lithuanians and $72 \%$ of Latvians indicated Russian as the second one.

The p-task was made up of $36 \%$ Lithuanian and $37 \%$ Latvian participants with higher education, LT $62 \%$ / LV 32\% with secondary school education, $2 \%$ LT and $20 \%$ LV with vocational secondary education and $11 \%$ Latvian participants with primary school education. Most of the participants in the paper task were from the fields of exact sciences, whereas humanities and social sciences were represented by $18 \%$ Lithuanian and $34 \%$ Latvian participants.

Most of the participants that completed the e-task were with higher education (Lithuanians 74\%, Latvians 75\%). $21 \%$ of Lithuanians and $15 \%$ of Latvians had secondary school education, 3\% Lithuanians and 7\% Latvians - vocational secondary education. Humanities and social sciences were reported the most frequent fields of education for both Lithuanians $(72 \%)$ and Latvians $(60 \%)$, the rest indicated engineering, natural sciences, medical, agriculture or other fields.

The demographic part of the e-task ended with the question about handedness: there were $95 \%$ right-handed and 5\% left-handed Lithuanian participants as opposed to $92 \%$ right-handed and $8 \%$ left-handed Latvian participants.

\section{Results and discussion}

\subsection{Data}

We further describe the data of each language and compare the results between Latvian and Lithuanian taking into account the format differences (i.e., p-task and e-task). We analyze how stimuli differing in axis (horizontal / vertical / oblique) and distance (when the circles are externally connected or disconnected and located far or close from each other) induce differences in descriptions. The data are organized in 3 tables according to the axis.

\subsubsection{Results for the horizontal axis}

When specifying the location of the dark circle on the horizontal axis, the participants of both languages usually employ the relative frame of reference locating the dark circle on the right or left side of the light circle (see Table 3). The absolute frame of reference is also chosen, namely the location of the dark circle, which is described using cardinal directions: it is located to the East or the West of the light circle. The results of the p-task of Lithuanian participants show that this strategy is not frequent - it occurs in $7 \%$ of the cases for every of the horizontal axis stimulus. However, responding to the e-task, the absolute frame of reference was almost never used. The same must be said of Latvian data in both tasks: the means of absolute frame of reference never exceed $5 \%$. 
Table 3. Results for the horizontal axis stimuli, $\%$

\begin{tabular}{|c|c|c|c|c|c|c|c|c|c|c|c|c|c|}
\hline \multirow[b]{3}{*}{$\begin{array}{l}\text { Conceptual } \\
\text { categories }\end{array}$} & \multirow{3}{*}{ 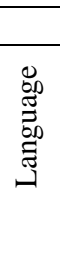 } & \multicolumn{2}{|c|}{1} & \multicolumn{2}{|c|}{5} & \multicolumn{2}{|c|}{9} & \multicolumn{2}{|c|}{3} & \multicolumn{2}{|c|}{7} & \multicolumn{2}{|c|}{11} \\
\hline & & \multicolumn{2}{|c|}{00} & \multicolumn{2}{|c|}{00} & \multicolumn{2}{|c|}{$\infty$} & \multicolumn{2}{|c|}{00} & \multicolumn{2}{|c|}{00} & \multicolumn{2}{|c|}{$\infty$} \\
\hline & & 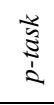 & $\frac{\vec{J}}{i}$ & $\begin{array}{l}\frac{u}{\vec{s}} \\
\text { i } \\
\end{array}$ & 范 & $\begin{array}{l}\frac{w}{2} \\
\vdots \\
\vdots \\
2\end{array}$ & 范 & 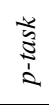 & 范 & 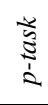 & 峁 & $\begin{array}{l}\text { 峁 } \\
\frac{1}{0}\end{array}$ & 范 \\
\hline \multirow[t]{2}{*}{ RIGHT $^{2}$} & LT & 82 & 84 & 84 & 80 & 82 & 77 & & & & & & \\
\hline & $\mathbf{L V}$ & 89 & 83 & 89 & 80 & 73 & 77 & & & & & 2 & \\
\hline \multirow[t]{2}{*}{ LEFT } & LT & & & & & & & 87 & 80 & 93 & 82 & 76 & 74 \\
\hline & $\mathbf{L V}$ & & & & & 7 & & 87 & 85 & 84 & 88 & 76 & 73 \\
\hline \multirow[t]{2}{*}{ EAST } & LT & 7 & 2 & 7 & 3 & 7 & - & & & & & & \\
\hline & LV & 2 & 5 & - & 5 & - & 3 & & & & & & \\
\hline \multirow[t]{2}{*}{ WEST } & LT & & & & & & & 7 & 2 & 7 & - & 7 & 3 \\
\hline & $\mathbf{L V}$ & & & & & & & - & 3 & 2 & 3 & 2 & 3 \\
\hline NEAR & LT & 4 & 12 & 9 & 19 & 22 & 33 & 4 & 12 & 10 & 20 & 30 & 39 \\
\hline šalia 'next to' & & $2 \%$ & $2 \%$ & $7 \%$ & $8 \%$ & 13 & 21 & $4 \%$ & $2 \%$ & $4 \%$ & $7 \%$ & $20 \%$ & $21 \%$ \\
\hline greta 'beside' & & & $2 \%$ & & $2 \%$ & $2 \%$ & $5 \%$ & & $3 \%$ & & $8 \%$ & $2 \%$ & $6 \%$ \\
\hline prie 'near' & & & $2 \%$ & & $2 \%$ & & $3 \%$ & & $2 \%$ & & $2 \%$ & $4 \%$ & $11 \%$ \\
\hline prie pat 'right at' & & & & & & $7 \%$ & $2 \%$ & & & & & $4 \%$ & \\
\hline šone 'at the side' & & & $3 \%$ & & & & & & & & & & \\
\hline kartu 'together' & & & & & $2 \%$ & & & & & & & & \\
\hline netoli 'not far' & & $2 \%$ & $3 \%$ & $2 \%$ & $5 \%$ & & & & $3 \%$ & $4 \%$ & $3 \%$ & & \\
\hline arti, arčiau 'close, closer' & & & & & & & $2 \%$ & & $2 \%$ & $2 \%$ & & & \\
\hline NEAR & LV & 9 & 3 & 15 & 5 & 35 & 31 & 9 & 7 & 13 & 5 & 35 & 30 \\
\hline blakus 'next to' & & $7 \%$ & $3 \%$ & 11 & $3 \%$ & 33 & 27 & $9 \%$ & $5 \%$ & 11 & $5 \%$ & $33 \%$ & $28 \%$ \\
\hline līdzās 'beside' & & & & & $2 \%$ & & $2 \%$ & & & & & & $2 \%$ \\
\hline cieši klāt 'tightly at' & & & & & & & $2 \%$ & & & & & & \\
\hline pie 'near' & & & & & & $2 \%$ & & & & & & $2 \%$ & \\
\hline netālu 'not far' & & $2 \%$ & & & & & & & $2 \%$ & & & & \\
\hline tuvu 'close' & & & & $4 \%$ & & & & & & $2 \%$ & & & \\
\hline FAR & LT & 18 & 13 & 2 & 2 & - & - & 13 & 13 & 2 & - & - & - \\
\hline toli / toliau ' $\mathrm{far}$, farther' & & 18 & 11 & $2 \%$ & $2 \%$ & & & 11 & 11 & $2 \%$ & & & \\
\hline atskirai 'separately' & & & & & & & & $2 \%$ & & & & & \\
\hline atokiai 'rather far from' & & & $2 \%$ & & & & & & $2 \%$ & & & & \\
\hline FAR & LV & 9 & 8 & 4 & 3 & - & - & 13 & 4 & 2 & 3 & - & - \\
\hline atstatus 'apart' & & $9 \%$ & & $4 \%$ & & & & $9 \%$ & & $2 \%$ & & & \\
\hline tälu, tâlumāa 'far' & & & $8 \%$ & & $3 \%$ & & & $4 \%$ & $2 \%$ & & $3 \%$ & & \\
\hline nostäk 'away from’ & & & & & & & & & $2 \%$ & & & & \\
\hline \multirow{2}{*}{$\begin{array}{l}\text { distance-speci- } \\
\text { fying phrases }\end{array}$} & LT & 13 & 7 & 13 & 2 & - & - & 11 & 3 & 9 & 2 & - & - \\
\hline & $\mathbf{L V}$ & 7 & 10 & 7 & 15 & - & - & 9 & 15 & 4 & 12 & - & - \\
\hline \multirow[t]{2}{*}{ non-top-verbs } & LT & 56 & 15 & 42 & 16 & 29 & 7 & 58 & 21 & 53 & 18 & 29 & 5 \\
\hline & $\mathbf{L V}$ & 22 & 20 & 40 & 20 & 27 & 22 & 42 & 22 & 38 & 23 & 31 & 17 \\
\hline \multirow[t]{2}{*}{ top-verbs } & LT & 2 & - & 2 & - & 40 & 28 & 2 & - & 2 & - & 42 & 20 \\
\hline & $\mathbf{L V}$ & 2 & 5 & - & 10 & 27 & 25 & 2 & - & - & 5 & 24 & 25 \\
\hline
\end{tabular}

\footnotetext{
${ }^{2}$ Capitalized lexemes in the tables denote the conceptual component regardless of its linguistic form. For example, location on the right side in Lithuanian is expressed using a wide range of functional variants: dešinejj(e) (pusejje) [LOC] 'on the right (side)', $i$ dešine (pusę) 'to the right (side)', iš dešines (pusès) 'from the right side', po dešine (puse) 'on the right (side)', dešiniau [ADV] 'more to the right', dešinen [ILL] 'to the right', predicative construction tamsus apskritimas yra dešinysis 'the dark circle is the right one'.
} 
As the distance between the two circles throughout the stimuli decreases (stimuli $1>$ $5>9$ and $3>7>11$ ), the number of NEAR-terms for Lithuanian increases: respectively, $4 \%>9 \%>22 \%$ and $4 \%>10 \%>30 \%$ for p-task and $12 \%>19 \%>33 \%$ and $12 \%>$ $20 \%>39 \%$ for e-task. In the NEAR group, LT šalia and greta are the most common: they both indicate proximal location, but the former is used more often in standard Lithuanian. A larger amount of LT prie (11\%) occurs only for the stimulus 11 in e-task. LT prie in combination with the particle pat, namely, prie pat 'right at', is found for stimuli 9 and 11 and infer the connectedness of the circles. Conversely, netoli 'not far away' is found only for the stimuli with disconnected circles regardless the distance between them ( 1 and 3 with larger distance / 5 and 7 with smaller distance). Adverbs arti 'close', arčiau 'closer' occur for all three types of stimuli, however, very sporadically.

In Latvian, we see a similar but a slightly less homogenous situation in usage of NEAR-terms: the closer the circles are, the more NEAR-terms are used (with a minor exception for stimuli 3 and 7 of the e-task). The adposition blakus seems to be the central marker of proximity. Interestingly, the adverb netālu 'not far' is used only for stimuli 1 and 3, but $t и v и$ 'close to'- for 5 and 7 indicating that the former adverb allows larger distance than the latter. lìdzās 'next to, beside', pie 'near, at' and cieši klät 'tightly at' are used for externally connected circles mostly. Adverb cieši 'fast, tightly' in combination with klāt indicates connectedness. Additionally, stimuli 9 and 11 are sporadically expressed employing the phrase tieš $\bar{a}$ kontakt $\bar{a}$ 'in direct contact'.

FAR-terms occur most frequently for stimuli 1 and 3, and their number decreases for stimuli 5 and 7. Farness for stimuli 1 and 3 is described using LT toli 'far', toliau 'farther' and adverbs atskirai 'separately' and atokiai 'remotely' (18\%/13\% and $13 \% / 13 \%$ ), but stimuli 5 and 7 have a few cases of toli 'far'. Latvian employs somewhat different FAR-terms for the p-task and e-task: the former has only atstatus 'at a distance, apart, away' while the latter has tālu, tāluma 'far' and 'nostāk 'away, aside': they all occur $9 \% / 8 \%$ for stimulus 1 and $13 \% / 4 \%$ for stimulus 3 .

In addition to the NEAR and FAR categories, there is also a separate label "distancespecifying phrases" in the Table 3. It stands for the cases when subjects specify the distance between the circles using numerical or semi-numerical expressions. Both languages employ very similar strategies: the subjects spell out the distance using numbers, geometric measurements, such as radius, diameters, centimeters, lexemes LT puse, LV puse 'half', etc. There are also responses stating that the distance exists, but no precise description is provided, e.g., LT per atstuma 'in distance', tam tikru atstumu 'in certain distance', skiriamas tarpo 'separated by gap', LV attālumā 'in distance', ar atstarpi 'with distance', ir distance 'there is distance'. The rationale behind such a separate group of terms lies in its difference from the categories NEAR and FAR. Even though distance-specifying phrases are used for the disconnected circles only (stimuli 1 and 3, 5 and 7), and thus presuppose remoteness (as the category FAR), the description of the remoteness usually does not explicitly entail nearness or farness, but instead it states that the distance is present or estimates it, cf.:

Latvian

(1) Virzienā pa labi no neiekrāsotā apla, aptuveni tādā attālumāa, kas ir divas reizes lielāks par neiekrāsotā apla diametru. (stimulus 1)

'In the direction to the right from the unpainted circle, at about twice the distance of the diameter of the unpainted circle.' 
(2) Pa kreisi no gaišā, apmēeram divu aplu attālumāa. (stimulus 3)

'To the left of the light, about two circles away.'

(3) Pa labi nelielā attālumā. (stimulus 5)

'A short distance to the right.'

(4) Pa kreisi no otra un ar $\sim 1 / 2$ apla diametra lielu atstarpi. (stimulus 7)

'To the left from the other circle and with the distance of $\sim 1 / 2$ circle diameter.'

In addition to all the spatial means described above, verbs also highly contribute to the expression of spatial information. The responses in both languages include various verbs, and for this analysis, the verbs are divided into two groups: non-topological and topological verbs. The former describes the location of the dark circle (e.g., verbs meaning 'be, be located, be moved away') while the latter specifies the topological relation between the two circles (these are verbs meaning mostly contiguity and contact). The amount and distribution of these verbs are rather different throughout the stimuli and tasks.

In Lithuanian, there are a lot of differences in use of the verbs. The t-test shows a significant difference $(\alpha=0.05)$ between electronically and paper-and-pencil data collection methods regarding the length of the responses: in the p-task, Lithuanian participants use remarkably more words to describe the Figure's location than in the etask. Thus the number of verbs is also very different in both tasks. However, even though the number of verbs between the p-task and e-task differs significantly, the prevailing tendency is obvious. Stimuli 1 and 3 have the largest amount of nontopological verbs with two equally dominating verbs yra 'is' and (yra) nutoless '(is) moved away'. The same applies to the stimuli 5 and 7, for which the verbs yra 'is', nutolęs 'moved away', pasistūmèjęs 'pushed itself, moved', nubrëžtas 'drawn', skiriamas 'separated' are used. Such verbs are usually complemented by quantitative means specifying the remoteness of the dark circle from the light one, e.g.:

\section{Lithuanian}

(5) Per tris spindulius nutolęs ị dešinę. (stimulus 1) 'Moved away three radii to the right.'

(6) Nutolęs i rytus per $5 \mathrm{~cm}$. (stimulus 3) 'Moved away to the East $5 \mathrm{~cm} . '$

(7) Per spindulị nutolęs ị dešinę. (stimulus 5) 'Moved away one radius to the right.'

(8) Yra per pusę savo skersmens nutolęs ị kairę nuo balto skritulio. (stimulus 7) 'Is moved away half of its diameter to the left from the white circle.'

For the stimuli with externally connected circles (9 and 11), we observe a decrease of non-topological verbs (only yra 'is' is used) and an increase of the topological verbs which is most likely because of the necessity to specify the external connection of the circles. It is expressed by various forms of verbs meaning touching and snuggling, e.g., liečia, liečiasi, liestusi, yra prisilietęs 'touch', yra prigludęs, yra prisiglaudęs 'pressed itself to', susiglaude 'pressed to each other'.

\section{Lithuanian}

(9) Yra prisiglaudęs prie šviesaus apskritimo iš pastarojo dešinès. (stimulus 9) 'Pressed itself to the light circle from the right side of the latter.' 
(10) Dešinèje balto, susiglaudę. (stimulus 9)

'To the right of the white one, they are pressed to each other.'

(11) Yra balto apskritimo kairèje, liečiasi su juo. (stimulus 11) 'To the left of the white one, touching it.'

For Latvian, the statistical tests show no significant difference between the p-task and e-task regarding the length of the responses. But we can observe the same tendency as in Lithuanian: the number of verbs in the p-task is usually larger than in the e-task. However, if compared to Lithuanian, non-topological verbs (ir 'is', atrodas 'is located', ir novietots 'is placed') are distributed differently. Non-topological verbs are distributed quite consistently for all the stimuli of both tasks, thus there is not such a considerable decrease of non-topological verbs for the $E C$ stimuli (9 and 11) as in Lithuanian. Nevertheless, the number of topological verbs significantly increases for the $E C$ stimuli. However, this increase is not as substantial as in Lithuanian. In Latvian, mostly the verbs saskaras 'touch each other', pieskaras, aizskar 'touches' are used.

\subsubsection{Results for the vertical axis}

Descriptions of the stimuli for the vertical axis show more variation because verticality is expressed by more diverse orientational means than horizontality in the Baltic languages (see Table 4). In stimuli 2, 6 and 10, the dark circle is located in the upper region from the light one and its location is expressed by various ABOVE-terms, namely, LT virš 'above', viršuje 'on the top', $i$ viršu 'to the top', iš viršaus 'from above', tiesiai virš 'right above', viršutinis 'one that is above'. The number of ABOVE-terms in Lithuanian is relatively high for all three stimuli $(82 \% / 84 \%$ for $2,84 \% / 85 \%$ for 6 , $82 \% / 74 \%$ for 10, see the data in Table 4). Stimuli 2 and 6 also have terms representing UP (aukštai 'high'/ aukščiau 'higher'/ aukštyn 'up'), but they appear more seldom (7\%/11\% for stimulus 2 and 7\%/7\% for stimulus 6). In Lithuanian, UP-terms presuppose a higher position of the dark circle on the vertical axis and involve disconnectedness. Because of this, there are no UP-terms for externally connected circles in stimulus 10 . Instead, stimulus 10 has $7 \% / 15 \%$ of ON (preposition ant). Usually, the LT ant 'on' requires relation of functional support, but in the stimuli set within the $\mathrm{RCC}+\mathrm{F}$ framework, such an interpretation is rather marginal because the participants focus on geometric properties mostly, but not functional ones (more on support in RCC see Žilinskaitè-Šinkūnienè et al., 2019a).

In Latvian, the distribution of ABOVE- and UP-terms do not differ as much as in Lithuanian: ABOVE (virs 'above', virsū 'on the top', virspusē 'on the top side', virsējais 'one that is above') and UP (augšā 'up', uz augšu 'upwards', augšpuse 'on the upper side', augstu 'high', augstāk 'higher', augšejais 'the one that is higher') occur for all the three stimuli, and the numbers do not exhibit such a big gap. Moreover, in contrast to Lithuanian, Latvian UP-terms (augš $\bar{a})$ are not limited to disconnectedness, thus they are used to describe stimulus 10. Latvian $u z$ 'on', occurs even more rarely than Lithuanian ant 'on': it is used only in 7\% of responses for stimulus 10 in the paper task.

Stimuli 4, 8 and 12 depict the dark circle in the lower region of the white circle and are described employing orientational terms BELOW, DOWN and UNDER. In Lithuanian, BELOW-terms are most frequent (apačioj 'below', $i$ apačia 'downwards', iš apačios, nuo apačios 'from below', apatinis 'one that is below'). DOWN-terms (žemai 'low, below'/ žemyn 'down'/ žemiau 'lower') are used more frequently when the circles 
are disconnected, because they presuppose a bigger distance downwards from the white circle (UP-terms are their counterpart in the upper region). UNDER-terms, namely LT po, po apačia 'under', po pat 'right under' are induced by connectedness as they are most frequently used for stimulus 12 , but their usage is not limited to the condition of connectedness only as it is the case for $\mathrm{ON}_{\text {-grams }}{ }^{3}$ on the vertical axis: ON-grams are confined to connectedness and support relations.

In contrast to Lithuanian, Latvian UNDER-terms cover the majority of the cases: zem occurs $51 \% / 52 \%$ for stimulus $4,58 \% / 35 \%$ for stimulus 8 and $64 \% / 50 \%$ for stimulus 12 . BELOW (apakša 'below', apakšpusē 'on the lower side', apakšejais 'one that is below') and DOWN (lejā 'down', uz leju 'downwards', lejpus 'below') are used more rarely.

The orientation of the dark circle on the vertical axis is also described applying cardinal directions (the absolute frame of reference). Again, as already observed in respect to the horizontal axis, in the p-task, Lithuanians use cardinal directions for all the stimuli of the vertical axis regardless the distance between the circles (11\% for the stimulus 2 and $7 \%$ for the rest of the stimuli). In LT e-task and Latvian data, it is used only sporadically as the amount of such responses usually does not exceed $5 \%$.

Table 4. Results for the vertical axis stimuli, \%

\begin{tabular}{|c|c|c|c|c|c|c|c|c|c|c|c|c|c|}
\hline \multirow[b]{3}{*}{$\begin{array}{l}\text { Conceptual } \\
\text { categories }\end{array}$} & \multirow{3}{*}{ 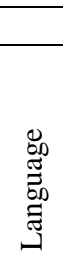 } & \multicolumn{2}{|c|}{2} & \multicolumn{2}{|c|}{6} & \multicolumn{2}{|c|}{10} & \multicolumn{2}{|c|}{4} & \multicolumn{2}{|c|}{8} & \multicolumn{2}{|c|}{12} \\
\hline & & \multicolumn{2}{|c|}{0} & \multicolumn{2}{|c|}{$\begin{array}{l}\circ \\
0\end{array}$} & \multicolumn{2}{|c|}{8} & \multicolumn{2}{|c|}{0} & \multicolumn{2}{|c|}{$\begin{array}{l}0 \\
0\end{array}$} & \multicolumn{2}{|c|}{8} \\
\hline & & 峁 & 范 & 范 & 范 & 峁 & 范 & 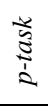 & 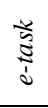 & 岂 & 范 & 萑 & $\underset{\frac{3}{3}}{i}$ \\
\hline \multirow{2}{*}{$\begin{array}{l}\text { ABOVE / VIRŠ, } \\
\text { VIRS }\end{array}$} & LT & 82 & 84 & 84 & 85 & 82 & 74 & & & & & & \\
\hline & $\mathbf{L V}$ & 60 & 38 & 60 & 45 & 60 & 50 & & & & & & \\
\hline \multirow{2}{*}{$\begin{array}{l}\text { UP / AUKŠTAI, } \\
\text { AUGŠ } \bar{A}\end{array}$} & LT & 7 & 11 & 7 & 7 & - & - & & & & & & \\
\hline & $\mathbf{L V}$ & 40 & 48 & 38 & 48 & 27 & 42 & & & & & & \\
\hline \multirow{2}{*}{$\mathbf{O N} / a n t, u z$} & LT & & & & & 7 & 15 & & & & & & \\
\hline & $\mathbf{L V}$ & & & & & 7 & - & & & & & & \\
\hline \multirow{2}{*}{$\begin{array}{l}\text { BELOW /APA- } \\
\text { ČIOJ, APAKŠ } \bar{A}\end{array}$} & LT & & & & & & & 42 & 64 & 49 & 54 & 51 & 56 \\
\hline & $\mathbf{L V}$ & & & & & & & 16 & 23 & 11 & 30 & 20 & 30 \\
\hline \multirow{2}{*}{$\begin{array}{l}\text { DOWN / ŽEMAI, } \\
\text { LEJĀ }\end{array}$} & LT & & & & & & & 27 & 21 & 31 & 18 & 16 & 3 \\
\hline & $\mathbf{L V}$ & & & & & & & 16 & 12 & 22 & 13 & 16 & 10 \\
\hline \multirow{2}{*}{$\begin{array}{l}\text { UNDER / } \\
\text { PO, ZEM }\end{array}$} & LT & & & & & & & 18 & 10 & 20 & 21 & 27 & 28 \\
\hline & $\mathbf{L V}$ & & & & & & & 51 & 52 & 58 & 38 & 64 & 50 \\
\hline \multirow{2}{*}{ NORTH } & LT & 11 & 5 & 7 & 5 & 7 & 2 & & & & & & \\
\hline & $\mathbf{L V}$ & 4 & 5 & 2 & 2 & 4 & 2 & & & & & & \\
\hline \multirow[t]{2}{*}{ SOUTH } & LT & & & & & & & 7 & 3 & 7 & 7 & 7 & 3 \\
\hline & $\mathbf{L V}$ & & & & & & & 4 & 5 & 2 & 5 & - & 2 \\
\hline NEAR & LT & 4 & - & 2 & 7 & 17 & 5 & 2 & 2 & 4 & 8 & 15 & 7 \\
\hline šalia 'next to' & & $2 \%$ & & $2 \%$ & $2 \%$ & $7 \%$ & $2 \%$ & $2 \%$ & - & $2 \%$ & $2 \%$ & 11 & \\
\hline greta 'beside' & & & & & & $2 \%$ & $3 \%$ & & - & & $2 \%$ & & $5 \%$ \\
\hline prie 'near' & & & & & & $4 \%$ & & & - & & $2 \%$ & & \\
\hline prie pat 'right at' & & & & & & $4 \%$ & & & - & & & $2 \%$ & $2 \%$ \\
\hline labai arti 'very close' & & & & & & - & & & - & & & $2 \%$ & - \\
\hline netoli 'not far' & & $2 \%$ & & - & $5 \%$ & - & & - & $2 \%$ & $2 \%$ & $2 \%$ & & - \\
\hline
\end{tabular}

\footnotetext{
${ }^{3}$ The term gram is used after Svorou (1994): it denotes any grammatical element bearing spatial
} meaning. 


\begin{tabular}{|c|c|c|c|c|c|c|c|c|c|c|c|c|c|}
\hline NEAR & LV & - & - & 6 & 4 & 7 & 9 & 2 & 2 & 6 & 2 & 6 & 6 \\
\hline blakus 'next to' & & - & & $2 \%$ & $2 \%$ & $7 \%$ & $7 \%$ & - & $2 \%$ & $2 \%$ & $2 \%$ & $4 \%$ & \\
\hline tieši blakus 'right at' & & & & & & & & & & & & & $2 \%$ \\
\hline līdzāas 'beside' & & & & & & & & & & & & $2 \%$ & $2 \%$ \\
\hline cieši klāt 'tightly at' & & & & & & & $2 \%$ & & & & & & $2 \%$ \\
\hline netālu 'not far' & & & & $2 \%$ & $2 \%$ & & & & & $2 \%$ & & & \\
\hline tuvu 'close' & & & & $2 \%$ & & & & $2 \%$ & & $2 \%$ & & & \\
\hline FAR $($ toli, tolèliau $)$ & LT & 7 & 8 & - & - & - & - & 9 & 5 & - & - & - & - \\
\hline FAR & $\mathbf{L V}$ & 6 & 2 & 7 & 2 & - & - & 6 & 5 & - & 5 & - & - \\
\hline atstatus 'apart' & & $4 \%$ & $2 \%$ & $7 \%$ & $2 \%$ & & & $4 \%$ & $2 \%$ & & $2 \%$ & & \\
\hline tālu 'far' & & $2 \%$ & & & & & & $2 \%$ & $3 \%$ & & $3 \%$ & & \\
\hline \multirow{2}{*}{$\begin{array}{l}\text { distance-speci- } \\
\text { fying phrases }\end{array}$} & LT & 7 & 3 & 9 & - & - & - & 11 & 3 & 11 & 3 & - & - \\
\hline & $\mathbf{L V}$ & 11 & 17 & 4 & 12 & - & - & 13 & 15 & 9 & 10 & - & - \\
\hline \multirow[t]{2}{*}{ non-top-verbs } & LT & 58 & 23 & 49 & 21 & 22 & 7 & 57 & 21 & 44 & 15 & 27 & 7 \\
\hline & $\mathbf{L V}$ & 42 & 22 & 40 & 23 & 36 & 18 & 38 & 25 & 42 & 22 & 40 & 18 \\
\hline \multirow[t]{2}{*}{ top-verbs } & LT & 4 & - & 2 & 2 & 49 & 15 & - & - & 4 & - & 44 & 20 \\
\hline & $\mathbf{L V}$ & - & 7 & 4 & 7 & 24 & 30 & 2 & 5 & 4 & 7 & 13 & 23 \\
\hline
\end{tabular}

NEAR-terms are not frequent for the vertical axis in both languages. If horizontal and vertical axes are compared, proximity terms occur more frequently when the circles are aligned horizontally. In the vertical axis, NEAR-terms are mostly attested for stimuli $6 / 8$ and $10 / 12$. However, there is some intralinguistic variation between the tasks. For example, the LT data of the p-task and e-task are distributed differently: the p-task has the largest amount of proximity terms for the stimuli in which the circles are externally connected, namely $10(18 \%)$ and $12(15 \%)$, but in the e-task, proximity terms are most frequently used for stimuli $6(7 \%)$ and $8(8 \%)$ with the disconnected circles.

As already observed for the horizontal axis, proximity adpositions LT šalia 'next to', greta 'beside' and LV blakus 'next to' are the most common ones. LT prie pat 'right at' and LV cieši klāt 'tightly at' require connectedness - for this reason they are employed for stimuli 10 and 12. However, if compared to the horizontal axis, the vertical axis is described using fewer proximity terms. For example, Lithuanian lacks lexemes adopting a usage which is confined to a lateral position because of its lexical meaning, such as the adverb šne 'at the side'. The adverb kartu 'together' is not used, because it usually expresses accompaniment or comitative relation, and thus is also much more plausible in horizontal alignment. In Latvian, the vertical axis lacks the preposition pie 'near'.

FAR-terms in Lithuanian occur only for in the case of 2 and 4, in Latvian - also for 6 and 8 . In addition, Latvians more frequently specify the distance employing different numerical information, e.g.:

\section{Latvian}

(12) Virs (augšpusē) otra ap̣̦la un ar $2 x$ apḷ diametra lielu atstarpi. (stimulus 2) "Above (on the top) of the second circle and with the distance of $\sim 2$ circle diameters.'

(13) $\overline{\text { Zem balt }} \overline{\text {, }} \sim 2$ diametru attālum. (stimulus 4) 'Below the white one, at the distance of $\sim 2$ diameters.'

(14) Virs gaišă, apmēram 1 cm attālumāa. (stimulus 6) 'Above the light one, at about $1 \mathrm{~cm}$ distance.' 
(15) Tumšais aplis atrodas uz leju no baltā apḷa. attālums, aptuveni puse apla diametra. (stimulus 8)

'The dark circle is down from the white circle. The distance is about half the diameter of the circle.'

In Lithuanian, specification of distance usually goes together with the participle nutoless 'moved away'. In addition to quantitative information, lexemes indicating approximate distance are used, namely verbs denoting remoteness are modified by adverbs šiek tiek 'a little', gerokai 'by far', labiau 'more', cf.:

\section{Lithuanian}

(16) Šiaurëje nuo balto, nutolęs. (stimulus 2) 'In the North, moved away.'

(17) Maždaug per tris diametrus nutolęs nuo šviesaus ị apačią. (stimulus 4) 'Moved away approximately three diameters downwards from the light circle.'

(18) Virš balto, šiek tiek pakilęs virš jo. (stimulus 6) 'Above the white one, a little bit risen above it.'

(19) Nubrèžtas balto apskritimo apačioje. Centrai nutolę 2-3 cm vienas nuo kito. (stimulus 8)

'Drawn below the white circle. The centers are 2-3 cm apart.'

As already seen from the examples, verbs also highly contribute to the spatial information of distance and orientation. In Lithuanian, the usage of verbs in vertical alignment shows a similar pattern to the horizontal one: non-topological verbs are predominant for disconnected circles, but the number of topological verbs increases twice or even more for externally connected ones. For Lithuanian data, non-topological verbs are yra 'is', yra nulolęs '(is) moved away', yra pakilęs '(is) risen', yra skiriamas 'is separated by', nubrěžtas 'is drawn', topological - nesiliečia 'does not touch each other', atskirtas 'is separated'. The latter verbs are used for stimuli 2, 4, 6, and 8, but other verbs, usually indicating contact, occur for stimuli 10 and 12 with externally connected circles, namely, susiliete, susiliečia, liečia, liečiasi, liestusi 'touch', prisišliejęs 'is adjoined', prigludęs 'pressed itself to', susiglaudžia 'pressed to each other', e.g.:

\section{Lithuanian}

(20) Yra virš balto apskritimo, taip, kad jie nesiliečia. (stimulus 2) 'Is above the white circle in a way that they are not touching each other.'

(21) Žemiau balto, atskirtas. (stimulus 8)

'Lower than the white one, separated.'

(22) Virš balto apskritimo, liečiasi su juo. (stimulus 10) 'Above the white one, touches it.'

(23) Apačioje balto, prigludęs. (stimulus 12) 'Below the white one, pressed itself [to the white circle].'

(24) Prisišliejęs prie baltojo apskritimo iš pietu pusès. (stimulus 12) 'Adjoins the white circle from the Southern side.'

In Latvian, the use of verbs for the vertical axis is also very similar to the horizontal one, except for the fact that for stimuli 10 and 12 in the e-task, the number of topological 
verbs (saskaras, pieskarties, sastapties, saklauties, nepārklāt) exceeds the number of non-topological verbs (ir 'is', atrodas 'is located') indicating that EC is cognitively prominent, e.g.:

\section{Latvian}

(25) augšpusē pieskaras gaišajam aplim. (stimulus 10)

'Touches the light circle at the top.'

(26) Zem neiekrāsotā, saskaras vienā punktā. (stimulus 12)

'Under the non-colored (circle), they meet at one point.'

\subsubsection{Results for the oblique axis}

Table 5. Results for the oblique axis stimuli, \%

\begin{tabular}{|c|c|c|c|c|c|c|c|}
\hline \multirow[b]{3}{*}{ Conceptual categories } & \multirow{3}{*}{ 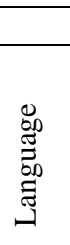 } & \multicolumn{2}{|c|}{17} & \multicolumn{2}{|c|}{18} & \multicolumn{2}{|c|}{19} \\
\hline & & \multicolumn{2}{|r|}{$\bigcirc$} & \multicolumn{2}{|c|}{$\mathrm{O}_{0}$} & \\
\hline & & p-task & e-task & $p$-task & e-task & $p$-task & e-task \\
\hline \multirow{2}{*}{$\begin{array}{l}\text { ABOVE / } \\
\text { viršs, virs }\end{array}$} & LT & 47 & 54 & & & & \\
\hline & $\mathbf{L V}$ & 18 & 10 & & & & \\
\hline \multirow{2}{*}{$\begin{array}{l}\text { UP/ } \\
\text { AUGŠTAI, AUGŠ̄̄ }\end{array}$} & LT & 9 & 3 & & & & \\
\hline & $\mathbf{L V}$ & 47 & 63 & & & & \\
\hline \multirow{2}{*}{$\begin{array}{l}\text { BELOW / } \\
\text { APAČIOJ, APAKŠĀ }\end{array}$} & LT & & & 33 & 31 & 46 & 28 \\
\hline & $\mathbf{L V}$ & & & 9 & 12 & 16 & 20 \\
\hline \multirow{2}{*}{$\begin{array}{l}\text { DOWN / } \\
\text { ŽEMAI, LEJĀ }\end{array}$} & LT & & & 20 & 18 & 13 & 15 \\
\hline & $\mathbf{L V}$ & & & 36 & 38 & 40 & 28 \\
\hline \multirow{2}{*}{$\begin{array}{l}\text { UNDER } \\
\text { po, zem }\end{array}$} & LT & & & 4 & 5 & 7 & 7 \\
\hline & $\mathbf{L V}$ & & & 24 & 18 & 18 & 17 \\
\hline \multirow[t]{2}{*}{ RIGHT } & LT & 56 & 46 & 58 & 43 & & \\
\hline & $\mathbf{L V}$ & 60 & 57 & 53 & 53 & & \\
\hline \multirow[t]{2}{*}{ LEFT } & LT & & & & & 54 & 38 \\
\hline & $\mathbf{L V}$ & & & & & 53 & 53 \\
\hline \multirow[t]{2}{*}{ NORTHEAST } & LT & 18 & 21 & & & & \\
\hline & $\mathbf{L V}$ & 9 & 10 & & & & \\
\hline \multirow{2}{*}{ SOUTHEAST } & LT & & & 18 & 25 & & \\
\hline & $\mathbf{L V}$ & & & 4 & 10 & & \\
\hline \multirow[t]{2}{*}{ SOUTHWEST } & LT & & & & & 18 & 23 \\
\hline & $\mathbf{L V}$ & & & & & 4 & 10 \\
\hline \multirow[t]{2}{*}{ OBLIQUE AXIS } & LT & 16 & 11 & 9 & 11 & 9 & 11 \\
\hline & $\mathbf{L V}$ & 13 & 17 & 20 & 13 & 22 & 12 \\
\hline NEAR & LT & 4 & 7 & 11 & 20 & 26 & 19 \\
\hline šalia 'next to' & & $2 \%$ & $2 \%$ & $2 \%$ & $7 \%$ & $9 \%$ & $11 \%$ \\
\hline greta 'beside' & & & $2 \%$ & & $5 \%$ & $4 \%$ & $3 \%$ \\
\hline prie 'near' & & & & & & $2 \%$ & $3 \%$ \\
\hline prie pat 'right at' & & & & & & $7 \%$ & $2 \%$ \\
\hline sone 'at the side' & & & & & & $2 \%$ & \\
\hline arti 'close' & & & & $2 \%$ & $5 \%$ & $2 \%$ & \\
\hline netoli 'not far' & & $2 \%$ & $3 \%$ & $7 \%$ & $3 \%$ & & \\
\hline
\end{tabular}




\begin{tabular}{|c|c|c|c|c|c|c|c|}
\hline NEAR & $\mathbf{L V}$ & & & 14 & 2 & 23 & 14 \\
\hline blakus 'next to' & & & & $7 \%$ & & $16 \%$ & $10 \%$ \\
\hline lìdzāa 'beside' & & & & & & & $2 \%$ \\
\hline pie, tieši pie 'near, right near' & & & & & & $7 \%$ & \\
\hline netālu 'not far' & & & & $7 \%$ & & & \\
\hline cieši tuvu 'tightly close' & & & & & $2 \%$ & & $2 \%$ \\
\hline FAR (toli, toliau, tolèliau) & LT & 11 & 13 & 2 & 2 & - & - \\
\hline FAR & $\mathbf{L V}$ & 8 & 7 & 4 & 7 & - & - \\
\hline atstatus 'apart' & & $4 \%$ & $2 \%$ & & $5 \%$ & & \\
\hline tālu, tālumā 'far' & & $4 \%$ & $3 \%$ & & $2 \%$ & & \\
\hline nostatus 'afar' & & & & $2 \%$ & & & \\
\hline attālāk 'remotely' & & & $2 \%$ & & & & \\
\hline sānis 'aside, apart' & & & & $2 \%$ & & & \\
\hline \multirow[t]{2}{*}{ distance-specifying phrases } & LT & 11 & 5 & 9 & - & - & - \\
\hline & $\mathbf{L V}$ & 7 & 12 & 7 & 8 & 2 & - \\
\hline \multirow[t]{2}{*}{ non-top-verbs } & LT & 53 & 20 & 42 & 13 & 35 & 8 \\
\hline & $\mathbf{L V}$ & 36 & 27 & 38 & 27 & 38 & 22 \\
\hline \multirow[t]{2}{*}{ top-verbs } & LT & 2 & - & 4 & 2 & 41 & 23 \\
\hline & $\mathbf{L V}$ & - & - & 4 & 5 & 22 & 27 \\
\hline
\end{tabular}

The description of the location on the oblique axis is the most complex, as it requires the greatest specification (see Table 5). Participants use the same orientational terms for above / below and left / right regions: ABOVE (LT aukštyn, aukščiau, LV augšā, augšejāa, uz augšu, augstu), UP (LT virš, LV virs) for stimulus 17, BELOW (LT apačioj, LV apakšāa, apakšpusē, apakšejais), DOWN (LT žemai, žemiau, žemyn, LV lejā, uz leju, lejpus) for stimuli 18, 19, and RIGHT $(17,18)$ / LEFT (19), but their quantity is smaller than for horizontal or vertical axes. The only exception is observed for Latvian: the number of DOWN-terms increases if compared to the vertical axis. Also, it is worth mentioning that both languages lack ON-grams (LT ant, LV $u z$ ) for externally connected circles (stimulus 19). ON-grams are not frequent, even in the canonical vertical position (stimulus 10), thus it is not surprising that for the oblique axis that such a support interpretation is even more implausible.

Interestingly, participants used cardinal directions for the oblique axis more than for horizontal and vertical axes as cardinal directions are a convenient way to refer to obliqueness. It is rather obvious for Lithuanian: 18\%/21\% (stimulus 17), 18\%/25\% (stimulus 18) and $18 \% / 23 \%$ (stimulus 19). In Latvian, however, this increase is not as evident: LV 9\%/10\% for stimulus 17 and 4\%/10\% for stimuli 18 and 19.

In addition to cardinal directions, both languages employ other strategies for obliqueness. These are the terms for the oblique axis: LT diagonaliai, istrižai 'diagonally' and LV diagonāli, slīpi, šķērsām 'idem', e.g.:

(27) LT toli, diagonaliai // 'far, diagonally'

(28) LT istrižai šone apačioje // 'obliquely, on the side, below'
LV pa diagonāli augšup (stimulus 17) 'diagonally upwards' LV ̌̌ķērsām blakus gaišajam (stimulus 19) 'obliquely, next to the light'

Moreover, diagonality is also expressed specifying the angle in degrees or clock arrows, cf. some Latvian and Lithuanian examples below. However, such metric descriptions never exceed $5 \%$ of the responses, e.g.: 
Latvian

(29) Tumšāk iekrāsotais aplis ir virs neiekrāsotā ap̣̦la gabaliņu attālāk, apmēram 45grādu lenk̦ī virzienā pa labi. (stimulus 17)

'The darker painted circle is above the unpainted circle, a bit farther away, at an angle of about 45 degrees to the right.'

(30) 45grādos pa labi. (stimulus 18) ' 45 degrees to the right.'

(31) 45 grädu leņk̄i zem baltā apḷa, pa kreisi. (stimulus 19) ' 45 degrees angle below the white circle to the left.'

\section{Lithuanian}

(32) Tolèliau balto apskritimo 1:30 laikrodžio kryptimi. (stimulus 17) 'Farther from the white circle at 1:30 clockwise.'

\section{Latvian}

(33) Ir nedaudz nostatus no gaišă apla pulkstena 4:30 virzienāa. (stimulus 18) 'Is slightly away from the light circle in 4:30 direction.'

(34) Pieskaras gaišajam aplim pulkstenaa 7:30 virzienā. (stimulus 19) 'Touches the light circle in 7:30 direction.'

Obliqueness is also expressed indirectly: the participant chooses the means that are typical for the vertical axis and then specifies it further with additional determining spatial descriptors, e.g.:

\section{Lithuanian}

(35) Yra po BA ir ne tiesiai po BA, o nutolęs i dešinę pusę. (stimulus 18)

'Is located under the white circle and not directly under, but is moved to the right side.'

The diversity of ways to describe oblique orientation leads to the observation that participants tend to use most words in responses and most precisely describe the location of the circles for the stimuli 17, 18 and 19 (see image 1 and image 2 in Škilters et al., submitted).

The usage of proximity terms shows a similar pattern as for the horizontal and vertical axes: as the distance between the circles decreases, the amount of spatial terms increases or remains approximately the same. In the case of the FAR category and distance-specifying phrases, the situation is reversed: the greater the distance, the more such responses are attested, e.g., stimulus 18 in LV:

\section{Latvian}

(36) Atrodas pa diagonāli (uz leju un pa labi) no baltā apḷa aptuveni 1/4 no apḷa diametra attālumā.

'Located diagonally (down and to the right) from the white circle at the distance of about $1 / 4$ of the circle diameter.'

Interestingly, in Latvian the distance is also indicated for the externally connected circles in stimulus 19, but if we look at this example more carefully, we see that the distance from the horizontal and vertical axes is meant, not from the white circle: 


\section{Latvian}

(37) Vienādā attālumā pa kreisi un zem. Ir kopīgs punkts.

'In equal distance to the left and under. There is a common point.'

Verbs are used in a similar way as in the responses to other axes. In Lithuanian, as the distance between the circles decreases, the number of non-topological verbs also decreases, but topological verbs become predominant. LT yra 'is' is used in the majority of cases, but there are also verbs that indicate remoteness of the dark circle, such as LT nutolęs, atitolęs 'moved away'. Stimulus 19 has 35\%/8\% of non-topological verbs, but $41 \% / 23 \%$ of topological verbs (liečiasi, yra prisilietęs 'touches', prisiglaudęs 'pressed itself to', prijungtas 'connected to'), e.g.:

\section{Lithuanian}

(38) Pietvakariuose. Prisilietęs prie balto apskritimo.

'In the Southwest. Touches the white circle.'

(39) Jis yra ties 7-8 valanda, liečiasi su šviesiuoju apskritimu. 'It is at 7-8 o'clock, in contact with the light circle.'

(40) Yra prie sviesaus apskritimo prisiglaudes istrizai kaireje puseje. 'It is near the white circle, pressed itself to it diagonally on the left side.'

(41) Istrižai iš apačios prijungtas prie baltojo. 'Diagonally from below connected to the white one.'

In Latvian, the same stimulus, 19, has 38\%/22\% of non-topological verbs ( $i r$ 'is', atrodas 'is located', ir nobìdits 'is moved from', attālināts 'moved away') and $22 \% / 27 \%$ of topological ones (saskaras 'touches each other', pieskaras 'touches smth', ir kombinācijā ar balto apli 'is in combination with the white circle'). Thus, non-top-verbs remain predominant for the $\mathrm{p}$-task, but in the e-task the number of top-verbs exceeds the number of non-top-verbs. In Lithuanian, however, the top-verbs for EC circles are predominant in both tasks.

\subsection{The usage of proximity and distance terms}

Figure 2 below presents the distribution of NEAR-terms for horizontal (stimuli 1-11 from the left side), vertical (stimuli 2-12 in the middle) and oblique (17-19) axes in both tasks and in both languages. The stimuli within the horizontal and vertical axes are organized according to the decrease of the distance: stimuli $1 / 3$ and 2 / 4 depict large distance, $5 / 7$ and $6 / 8-$ small, but $9 / 11$ and $10 / 12$ have no distance between the circles, as the circles are externally connected.

The data in the Figure 2 show a strong link between the stimulus type in relation to distance between the circles and the usage of NEAR-terms: as the distance between the circles decreases, the number of proximity terms increases. In addition, the horizontal axis seems to be the most compatible with proximity terms and, moreover, the horizontal axis has the highest variety of proximity terms. The oblique axis (stimuli 17, 18 and 19) follows the horizontal one in respect to the frequency of proximity terms, but the vertical axis has least of them. The vertical axis is different not only in frequency of these terms, but also in scope: in Lithuanian, it lacks adverb šone 'at the side' which is present for the other axes, but in Latvian pie 'near', tieši pie 'right near' are absent for the verticality. 


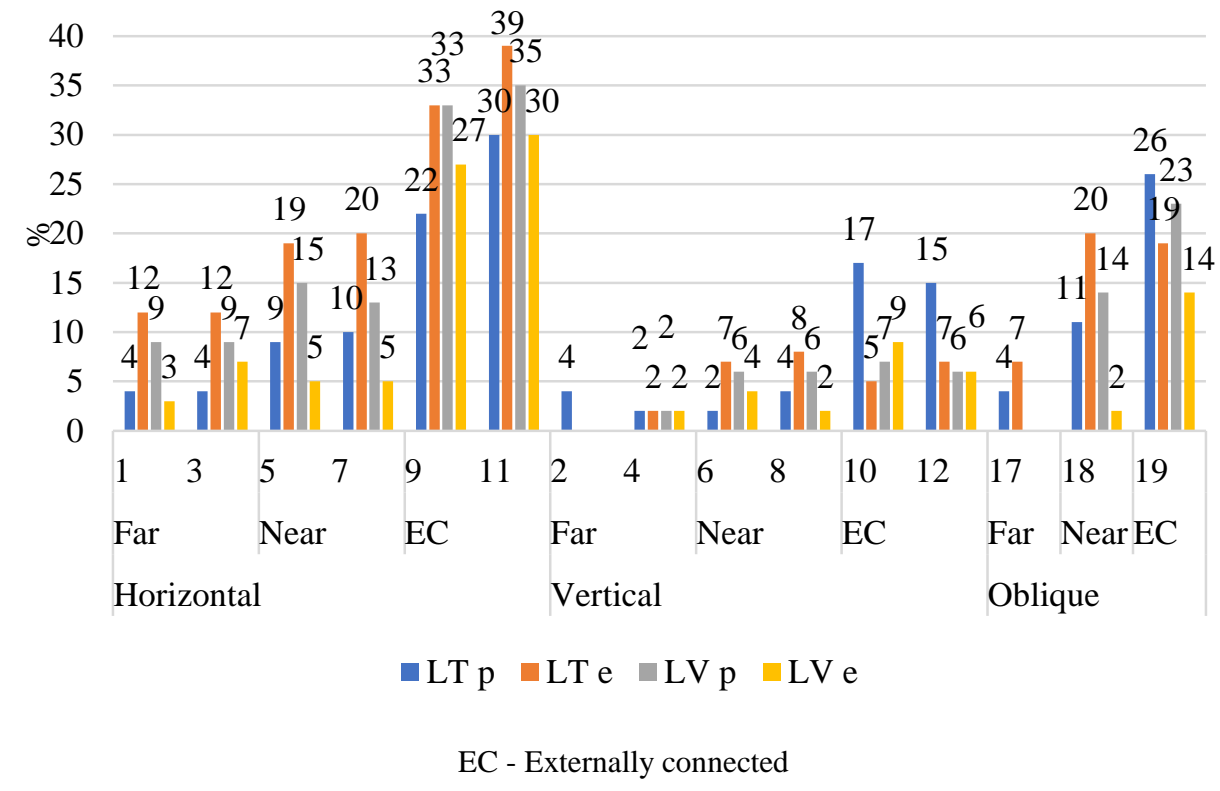

Figure 2. Usage of NEAR-terms for horizontal, vertical and oblique axes, (\%)

Moreover, if we look at the diversity of spatial terms indicating proximity, we see that in the vast majority of cases, LT šalia 'next to', greta 'beside' and LV blakus 'next to' are used. In Lithuanian, these prepositions usually describe location and coexistence of the Figure and the Ground in vicinity to each other, and often presuppose the same status resp. symmetry of these two basic elements of the spatial scene. Moreover, they do not presuppose any interaction between the Figure and the Ground; the same must be said about the Latvian blakus. In contrast, prepositions LT prie and LV pie occur very sparsely in the data of both languages, as the semantic scope of these prepositions is usually not limited to pure locative relation between the objects of equal status. LT prie and LV pie may entail Figure-Ground asymmetry and functional interaction. Therefore, the participants use LT šalia, greta and LV blakus to locate the light circle, but the connectedness (and possible interaction) is expressed by the verbs (see discussion section).

Figure 3 below shows the usage of FAR terms. Obviously, externally connected circles have no FAR-terms in the responses. For the rest of the stimuli, the frequency of FAR-terms is relatively opposite to NEAR-terms, because the larger the distance is, the more FAR expressions are used by the participants: the largest number of them is observed for the stimuli $1 / 3$ (the horizontal axis), less for the stimulus 17 (the oblique axis) and least for $2 / 4$ (the vertical axis) with the circles displaying remote disconnectedness. If the distance between the circles is smaller $(5 / 7$ for the horizontal axis, 6 / 8 for the vertical axis and 18 for the oblique axis), the distribution of FAR-terms is relatively similar for the horizontal and oblique axes, but the vertical axis varies according to the language: Lithuanian has no FAR-terms at all, but Latvian does. The Baltic languages also differ in respect to the array of lexemes. In Lithuanian, the horizontal axis has most adverbs for farness: toli / toliau 'far, farther', atskirai 


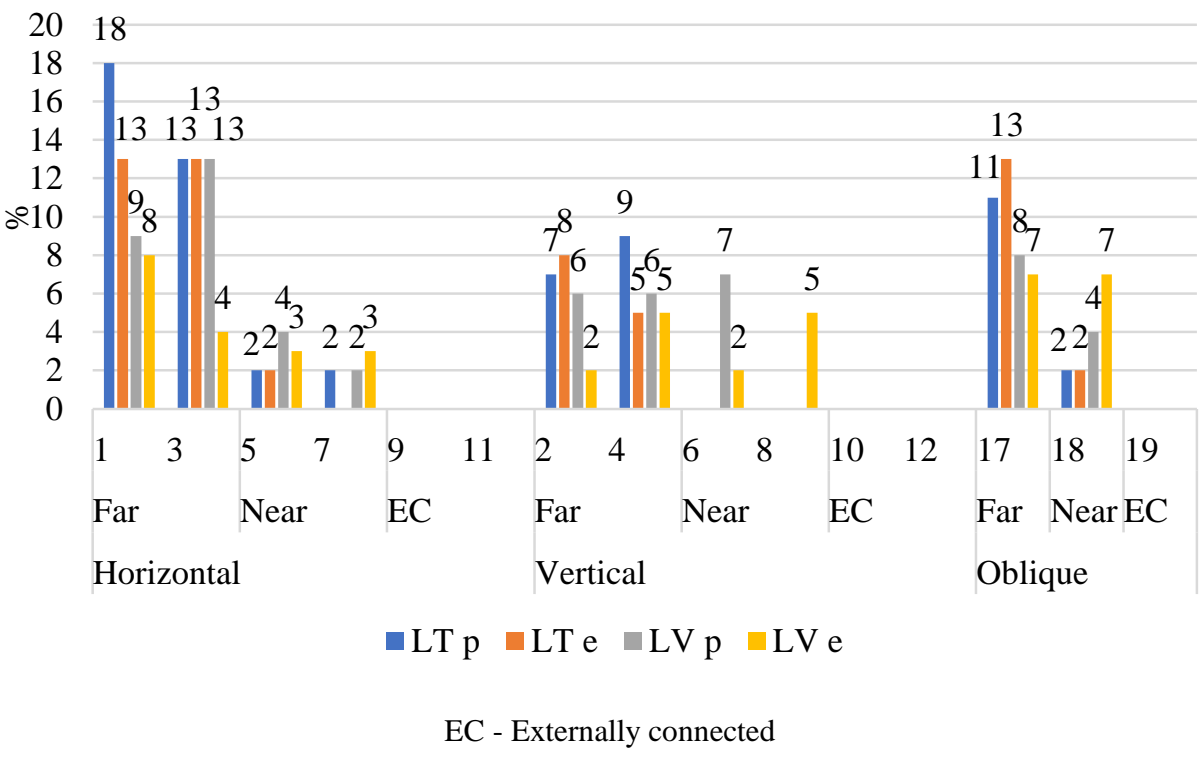

Figure 3. Usage of FAR-terms for horizontal, vertical and oblique axes, (\%)

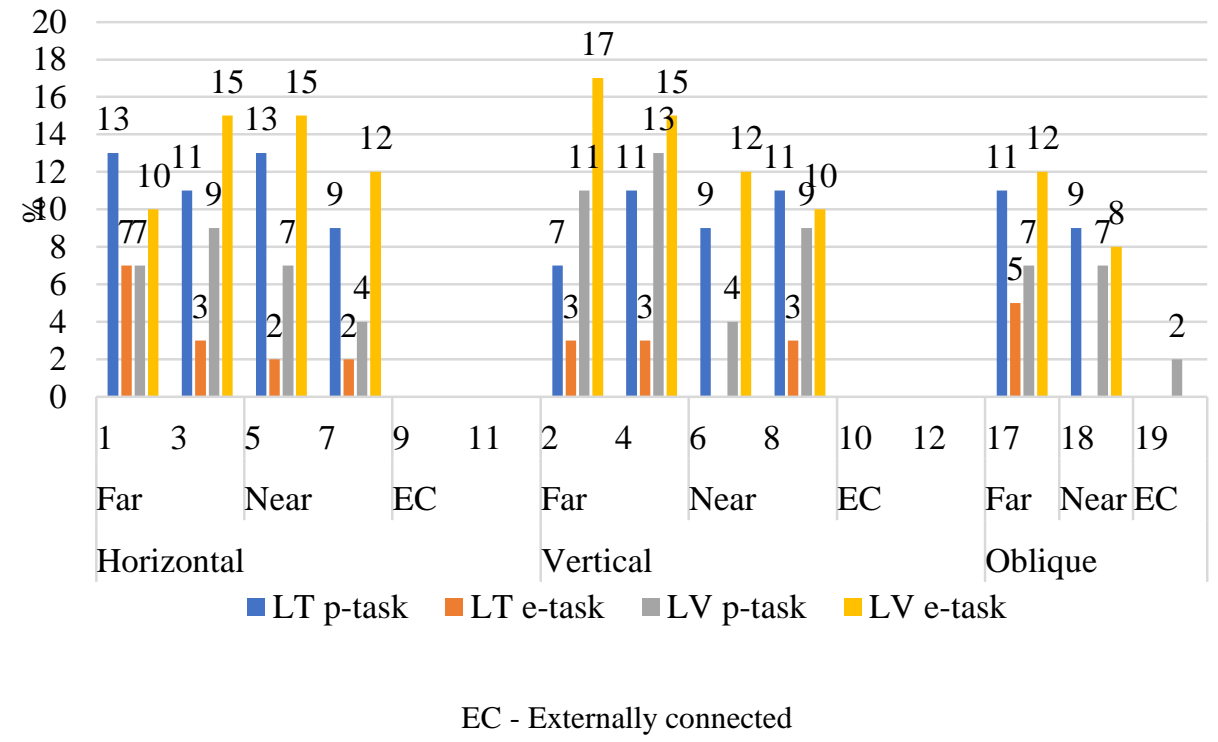

Figure 4. Usage of distance-specifying phrases for horizontal, vertical and oblique axes, (\%) 
'separately', atokiai 'rather far from', but the remaining axes are characterized by toli 'far' / toliau / toleliau 'farther' only. In Latvian, however, the oblique axis has most lexemes, such as atstatus 'apart', nostatus 'afar', tālu, tālumā 'far', attālāk 'remotely', sānis 'aside, apart', horizontal - atstatus 'apart', tālu, tālumā 'far', nostāk 'away from', whereas the vertical axis - only atstatus 'apart' and tālu 'far'.

Figure 4 displays the results of distance-specifying phrases. This category is characterized by expressions attempting to indicate a concrete distance between the circles employing geometric terms, metric information, adverbial modifiers (e.g., tam tikru atstumu 'at certain distance') etc. The responses do not include such information for externally connected circles ( $2 \%$ for stimulus 19 in LV p-task seem to indicate the distance from $\mathrm{x}$ and $\mathrm{y}$ axes, not from the white circle). For the rest of the stimuli, certain axes and increase / decrease in distance do not influence the usage of distance specifiers in the same way as for NEAR- or FAR-terms. The presence of any distance seems to be a determining factor for attempting to express it in certain measurements.

\subsection{Discussion and conclusions}

Our results show that both topological and geometric knowledge determines spatial descriptions in $\mathrm{RCC}+\mathrm{F}$ framework. When specifying the location of the dark circle in all three axes, orientational terms of the relative frame of reference seem to be the most prominent and frequent ones, as they structure space into robust categories: the horizontal axis is primarily described using LEFT / RIGHT-terms, but vertical ABOVE / UP / ON and BELOW / DOWN / UNDER. For the oblique axis, the terms referring to both verticality and horizontality are used with a slight predominance of the former ones. In addition, in the Lithuanian sample, the oblique axis has a larger number of responses containing cardinal directions (the absolute frame of reference) than the remaining two axes. Moreover, subjects of both languages use different other strategies to express obliqueness: lexemes denoting diagonality (LT diagonaliai, istrižai, LV diagonāli, slīpi, šksērsām), metric information (angle specification with degrees or clock arrows), and indirect descriptions referring to obliqueness with the means that are characteristic of other axes.

The terms that express proximity (NEAR-terms) or remoteness (FAR-terms) and specify distance between the circles are used to a lesser extent and thus are of secondary importance. However, all of them not only contribute to the localization of the Figureobject, thus making the description more accurate, but also reveal different determining variables that underline the usage of these terms. Axial information, distance and connectedness affect the usage of NEAR-terms, axial information and disconnectedness - of FAR-terms, disconnectedness and presence of any distance - of distance-specifying phrases.

One interesting finding is that connectedness between the circles $(E C$, in particular) causes the largest number of NEAR-terms in $\mathrm{RCC}+\mathrm{F}$ framework. Even when the circles are connected and aligned vertically (stimulus 10), participants still use NEAR-terms and the number of NEAR-terms sometimes may even exceed the number of ON-grams. In this case, geometric information seems to be more important than support (ŽilinskaitèŠinkūnienè et al., 2019a). But if real-world spatial situations are considered, connectedness between everyday objects might indicate interaction between the Figure 
and the Ground, and therefore the Figure becomes constrained by the Ground in various ways; typical support prepositions are then used (the data for support category with everyday objects in the Baltic languages and Estonian can be found in ŽilinskaitèŠinkūnienè et al., 2019b).

In addition, connectedness (and eventually a possible interaction) has one more consequence: it substantially induces the application of topological verbs in $\mathrm{RCC}+\mathrm{F}$ framework. In Lithuanian, the usage of the verbs is consistent in relation to all the three axes: non-topological verbs are used for all types of stimuli, but their number decreases for the externally connected ones allowing topological verbs to take a predominant status. Hence the number of topological verbs for externally connected circles always exceeds the number of non-topological verbs. It is not usually the case in Latvian: nontopological verbs remain predominant when describing both disconnectedness (both tasks) and external connectedness (the p-task), but in the e-task the number of topological verbs exceed the non-topological verbs. However, this increase is not as considerable as in Lithuanian. These results are in line with our previous findings with support in $\mathrm{RCC}+\mathrm{F}$ : when expressing the location of the dark circle on the vertical axis under the conditions of partial overlap and partial occlusion, Lithuanian participants in both tasks and Latvian participants in the e-task use the topological verbs more than the non-topological ones (Žilinskaitè-Šinkūnienè et al., 2019a, 244).

The topological verbs express the connection of the circles in different perspectives. The circles may be treated as equal resp. symmetric members in a spatial scene employing reciprocal verbs LT susiliesti / LV saskarties 'touch each other', susijungti / savienoties 'join each other', LT susiglausti / LV saklauties 'press to each other', LV sastapies 'meet each other'. Also, participants may put emphasis on the Figure (the dark circle) and describe connection from its perspective using the verbs LT liesti, prisiliesti / LV pieskarties 'touch', LT prisišlieti 'adjoin', priglusti 'press itself to'. In the latter way, these verbs reflect Figure-Ground asymmetry and convey not only the topological information of connectedness, but also refer to the interactional element. This suggests that topological NEAR-terms are not efficient to reflect external connectedness of the circles as connectedness might also mean (a) interaction which causes the participants to additionally use an increased number of topological verbs, or (b) necessity of specification the exact area of contact between both regions.

The findings on expressing proximity and distance within an extended RCC framework lead to questions about the determining factors for them in the functional domain (resp. everyday situations). Although the participants produce most NEAR-terms for externally connected circles in $\mathrm{RCC}+\mathrm{F}$ framework, connectedness might not be necessary or relevant for expressions of proximity in real-world spatial scenes. Various other prominent causes should be taken into account, which, however, remains a question for future research.

\section{Abbreviations}

ADV - adverb, ILL - Illative, LT - Lithuanian, LV - Latvian, LOC - Locative. 


\section{Acknowledgements}

We would like to thank all the participants who kindly devoted their time and effort to participate in the experiment. We are grateful to Nora Bērziña for her assistance in coding the Latvian data. For Egle Žilinskaitė-Šinkūnienè, this project has received funding from the European Social Fund (project No 09.3.3-LMT-K-712-02-0134) under a grant agreement with the Research Council of Lithuania (LMTLT).

\section{References}

Bennett, D. C. (1975). Spatial and temporal uses of English prepositions: An essay in stratificational semantics. London: Longman.

Bowerman, M., Choi, S. (2003). Space under construction: Language-specific spatial categorization in first language acquisition. In: Gentner, D., Goldin-Meadow, S. (Eds.), Language in mind: Advances in the study of language and thought (pp. 387-427). Cambridge, MA: MIT Press.

Bowerman, M., Pedersen, E. (1992). Topological relations picture series. In: Levinson, S. C. (Ed.), Space stimuli kit 1.2, November 1992, 51. Nijmegen: Max Planck Institute for Psycholinguistics. Available at http://fieldmanuals.mpi.nl/volumes/1992/bowped/

Carlson, L. A., Hill, P. L. (2003). Experimental methods for studying language and space. In: Gonzalez-Marquez, M., Mittelberg, I., Coulson, S., Spivey, M. (Eds.), Methods in cognitive linguistics. Human cognitive processing 18 (pp. 250-276). Amsterdam / Philadelphia: John Benjamins Publishing Company.

Cienki, A. J. (1989). Spatial cognition and the semantics of prepositions in English, Polish and Russian. München, Berlin, Washington D.C.: Verlag Otto Sagner.

Cohn, A. G., Bennett, B., Gooday, J., Gotts, N. M. (1997). Qualitative spatial representation and reasoning with the region connection calculus. GeoInformatica 1(3), 275-316.

Cooper, G. S. (1968). A semantic analysis of English locative prepositions. Cambridge, New York, Chicago, Los Angeles: Bolt Beranek and Newman Inc.

Coventry, K. R., Carmichael, R., Garrod S. C. (1994). Spatial prepositions, object-specific function, and task requirements. Journal of semantics 11(4), 289-309.

Coventry, K. R., Garrod, S. C. (2004). Saying, seeing and acting: The psychological semantics of spatial prepositions. Hove and New York: Psychology Press.

Coventry, K. R., Valdés, B., Castillo, A., Guijarro-Fuentes, P. (2008). Language within your reach: Near-far perceptual space and spatial demonstratives. Cognition 108(3), 889-895.

Feist, M. I., Zhang, Y. (2019). Mapping space: comparative study. In: Goel, A., Seifert, C., Freksa, C. (Eds.), Proceedings of the 4lst Annual Meeting of the Cognitive Science society (pp. 1717-1723). Austin, TX: Cognitive Science Society.

Forbus, K. D. (2018). Qualitative representations: how people reason and learn about the continuous world. Cambridge, MA: The MIT Press.

Gentner, D., Bowerman, M. (2009). Why some spatial semantic categories are harder to learn than others: The typological prevalence hypothesis. In: Guo, J., Lieven, E., Budwig, N., ErvinTripp, S. M., Nakamura, K., Özçalişkan, Ş. (Eds.), Crosslinguistic approaches to the psychology of language: Research in the tradition of Dan Isaac Slobin (pp. 465-480). New York: Psychology Press.

Herskovits, A. (1986). Language and spatial cognition. An interdisciplinary study of prepositions in English. Cambridge: Cambridge University Press. 
Jamrozik, A., Gentner, D. (2011). Prepositions retain aspects of spatial meaning in abstract contexts. In: Carlson, L., Hoelscher, Ch., Shipley, T. F. (Eds.), Expanding the Space of Cognitive Science. Proceedings of the 33rd Annual Meeting of the Cognitive Science Society (pp. 1589-1594). Austin, TX: Cognitive Science Society. Available at: http://csjarchive.cogsci.rpi.edu/Proceedings/2011/papers/0358/index.html, accessed November 18, 2019.

Landau, B., Johannes, K., Skordos, D., Papafragou, A. (2017). Containment and support: Core and complexity in spatial language learning. Cognitive science 41(S4), 748-779. Available at: https://doi.org/10.1111/cogs.12389

Landau, B. (2017). Update on "What" and "Where" in spatial language: A new division of labor for spatial terms. Cognitive science 41(S2), 321-350. Available at: https://doi.org/10.1111/cogs.12410

Levinson, S. C. (2003). Space in language and cognition: Explorations in cognitive diversity. Cambridge: Cambridge University Press.

Levinson, S. C., Wilkins, D. P. (2006). Grammars of space. Cambridge: Cambridge University Press.

Majid, A., Bowerman, M., Kita, S., Haun, D. B. M., Levinson, S. C. (2004). Can language restructure cognition? The case for space. Trends in Cognitive Science 8(3), 108-114.

Mani, I., Pustejovsky, J. (2012). Interpreting motion: Grounded representations for spatial language. Oxford: Oxford University Press.

Navarro, I. (1998). A cognitive semantics analysis of lexical units AT, ON and IN in English. $\mathrm{PhD}$ Dissertation. Universitat Jaume I.

Randell, D. A., Cui, Z., Cohn, A. G. (1992). A spatial logic based on regions and connection. 3rd Int. Conf. on Knowledge Representation and Reasoning, 165-176.

Rodrigues, E., Santos, P. E., Lopes, M. (2017). Pinning down polysemy: A formalisation for a Brazilian Portuguese preposition. Cognitive systems research 41, 84-92.

Šarić, L. (2008). Spatial concepts in Slavic: A cognitive linguistic study of prepositions and cases. Harrassowitz Verlag.

Šķilters, J., Glanzberg, M., Žilinskaitè-Šinkūnienè, E., Zarina, L. (MS). RCC+F: some applications to spatial structure in the Baltic languages.

Šķilters, J., Zariņa, L., Žilinskaitè-Šinkūnienè, E., Bērziņa, N., Apse, L. (submitted). Topological and geometric structure of spatial relations in Latvian: an experimental analysis of RCC.

Svorou, S. (1994). The grammar of space. Amsterdam / Philadelphia: John Benjamins Publishing Company.

Talmy, L. (2000). Toward a cognitive semantics. Cambridge, MA: MIT Press.

Vandeloise, C. (1991). Spatial prepositions. A case study from French. Chicago and London: The University of Chicago Press.

Vandeloise, C. (2017). The expression of proximity in French and English. Corela: Cognition, représentation, langage, HS-23, 1-23. Available at: https://journals.openedition.org/corela/5036\#tocto1n3, accessed July 10, 2019.

Vasardani, M., Stirling, L. F., Winter, S. (2017). The preposition at from a spatial language, cognition, and information systems perspective. Semantics and pragmatics 10, Article 3, https://doi.org/10.3765/sp.10.3

Žilinskaitė-Šinkūnienè, E., Šḳilters, J., Zarina, L. (2019a). Containment and support in the Baltic languages: Overview, experimental evidence, and an extended RCC as applied to Latvian and Lithuanian. Baltic Journal of Modern Computing 7(2), 224-254. Available at: https://doi.org/10.22364/bjmc.2019.7.2.02

Žilinskaitè-Šinkūnienè, E., Šķilters, J., Zariņa, L., Bērziņa, N. (2019b). Containment and support: Similarities and variation in Lithuanian, Latvian and Estonian. Baltistica 54(2), 205-255, doi: 10.15388/Baltistica.54.2.2386. 